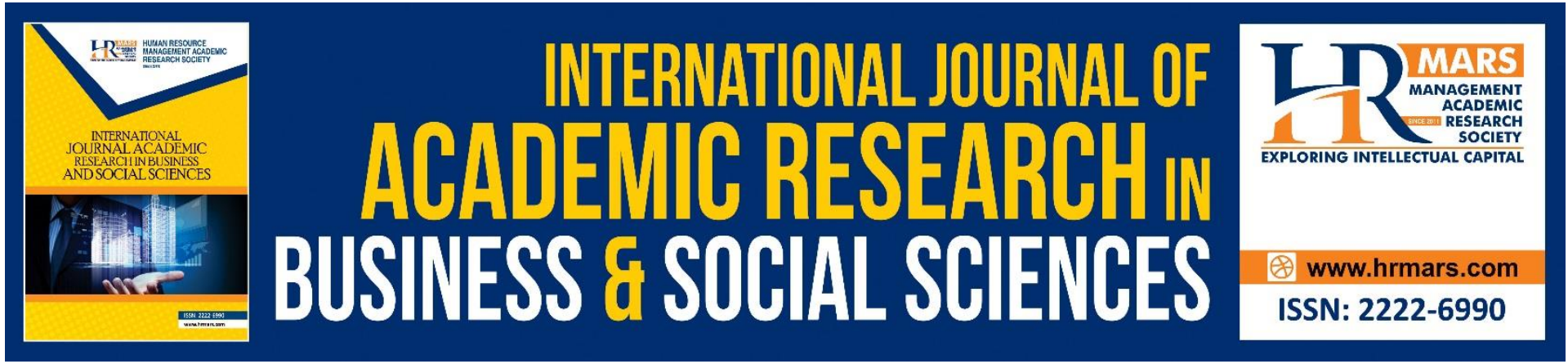

\title{
A Comparative Study of the Pursuit of Love of Layla and Zhu Yingtai in Light of Arabic and Chinese Cultural Perspectives
}

\author{
Ailifeire Aierken, Muhd Zulkifli Ismail, Syed Nurulakla Syed Abdullah \& Ser \\ Wue Hiong
}

To Link this Article: http://dx.doi.org/10.6007/IJARBSS/v11-i7/10345

DOI:10.6007/IJARBSS/v11-i7/10345

Received: 17 May 2021, Revised: 20 June 2021, Accepted: 05 July 2021

Published Online: 24 July 2021

In-Text Citation: (Aierken et al., 2021)

To Cite this Article: Aierken, A., Ismail, M. Z., Abdullah, S. N. S., \& Ser, W. H. (2021). A Comparative Study of the Pursuit of Love of Layla and Zhu Yingtai in Light of Arabic and Chinese Cultural Perspectives. International Journal of Academic Research in Business and Social Sciences, 11(7), 1138-1146.

Copyright: @ 2021 The Author(s)

Published by Human Resource Management Academic Research Society (www.hrmars.com)

This article is published under the Creative Commons Attribution (CC BY 4.0) license. Anyone may reproduce, distribute, translate and create derivative works of this article (for both commercial and non-commercial purposes), subject to full attribution to the original publication and authors. The full terms of this license may be seen at: http://creativecommons.org/licences/by/4.0/legalcode

Vol. 11, No. 7, 2021, Pg. 1138 - 1146

Full Terms \& Conditions of access and use can be found at http://hrmars.com/index.php/pages/detail/publication-ethics 


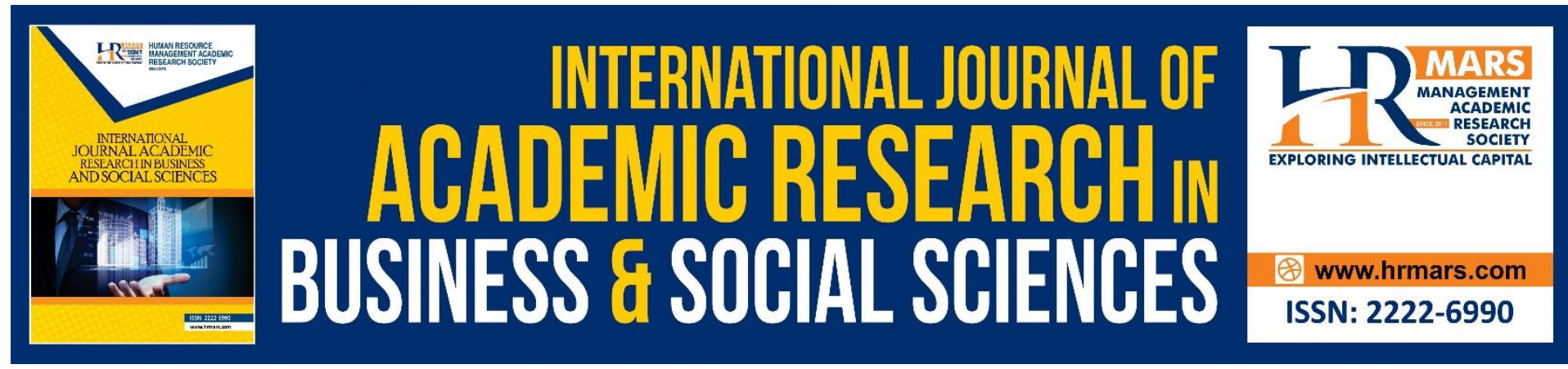

\title{
A Comparative Study of the Pursuit of Love of Layla and Zhu Yingtai in Light of Arabic and Chinese Cultural Perspectives
}

\author{
Ailifeire Aierken, Muhd Zulkifli Ismail, Syed Nurulakla Syed \\ Abdullah \& Ser Wue Hiong \\ Faculty of Modern Languages and Communication, Universiti Putra Malaysia
}

\begin{abstract}
In cultural exchanges between different countries, the comparative study of literary work has become a heated topic in modern academic research. Majnun Layla and Liang Shanbo and Zhu Yingtai are two well-known love tragedies in Arabic and Chinese Literature. Layla and Zhu Yingtai are heroines of two plays. In order to enhance a better understanding of the two plays and to deepen readers' aesthetic appreciation of these classic works, this study seeks to achieve the following objectives: to explore the difference between two heroines in defending love; to point out the similarities between two heroines in attitudes towards marriage. The method used in this research is the descriptive qualitative method. This study reveals that representation of human behavior can be seen through Layla and Zhu Yingtai, who experienced similar frustration. Layla and Zhu Yingtai's different ways of defending their love but similar attitudes towards their parents' arrangement of their marriages were affected by their social backgrounds. The matter is well-proved if considered in light of Arabic and Chinese cultural perspectives. A further study is suggested in the other comparison fields, such as the plot structure, theme, the male characters and plot setting.

Keywords: Social Background, Literature, Cultural Perspective, Pursuit of Love

\section{Introduction}

Love is an eternal theme in literature. Majnun Layla and Liang Shanbo and Zhu Yingtai are two well-known love tragedies, which depict young people who had the courage to pursue their love and resist the social forces. Majnun Layla is a well-known Middle Eastern classic, and it is about a love story between Qays Al-Mullawah and Layla Al-Ameriya in the 7th century Arabia. The legend of Liang Shanbo and Zhu Yingtai takes place during the Eastern Jin dynasty (265-420 AD). The story of Liang Shanbo and Zhu Yingtai is counted as China's Four Great Folktales, along with three other Legends, White Snake (Baishezhuan), Lady Meng Jiang, and The Cowherd and the Weaving Maid (Niulang Zhinü).
\end{abstract}

Many studies have compared Romeo and Juliet with Liang Shanbo and Zhu Yingtai and Majnun Layla, respectively. Many scholars have studied Liang Shanbo and Zhu Yingtai, and Romeo and Juliet from the standpoint of themes, plots, characteristics of the protagonists, and their artistic forms. For example, Tan Zongyan (2007) analyzed the 
differences between Romeo and Juliet and Liang Shanbo and Zhu Yingtai. Through the comparisons of the two works, the study explored their differences and related cultural orientations from their differences in the plots and leading characters. The study has found that these two tragedies, with similar plots, have high praise for freedom of love and oppose to feudalism. It is discovered that both Romeo and Juliet and The Butterfly Lovers have been exerting significant influences upon British, Chinese and even the whole world's literature.

Some other scholars appreciated them from the viewpoint of culture. For example, in 2002, Cheng Ying published a paper entitled The Magnificent Sun vs The Graceful Moon - A Proposed Analysis of the Differences between Romeo and Juliet and The story of Liang Shanbo and Zhu Yingtai the Cultural Contributing Factors of These Differences, which concluded that the two works differ in the character of the hero and heroine. Furthermore, the spirit of the tragedy, the denouement and their distinguishing features are closely related to their cultural backgrounds, respectively.

There are also comparative studies between Romeo and Juliet and Majnun Layla. For example, in 2016, an article name Forbidden Love of Shakespeare's Romeo and Juliet and Fuzûlî's Majnun Layla written by Nilay Avci has been published. The study looks at two major examples of stories with the theme of forbidden love. The author concluded that both of the works are based on archetypal themes. The only difference is, in Romeo and Juliet, there is hate and violence in addition to love and passion. In Layla and Majnun, when love becomes truly impossible, Majnun's love exceeds the limit of human love, turning into divine love.

Curiously, it is hard to find comparative study between Liang Shanbo and Zhu Yingtai and Majnun Layla. After a rigorous review of the relevant literatures, the researchers found two comparative studies between Majnun Layla and Liang Shanbo and Zhu Yingtai. The first study is a one-page short article, A Comparative study on Majnun Layla and Liang Shanbo and Zhu Yingtai, written by Jiao Yan, published in 2012. This study attempts to reveal different aesthetic demand in the diverse cultural background by comparing other emotional expressions of the two pairs of lovers. The author concluded that emotion expression and perception are affected by cultural backgrounds. Another study by Ding Shuhong (2006), $A$ Comparative Study of Arabic, Chinese and English Literature, compares Majnun Layla, Liang Shanbo and Zhu Yingtai and Romeo and Juliet. This study first summarizes the similarities and differences of the three plays in the aspects of the themes and characters, then points out that Chinese and Arabic tragedy are in different aesthetic attitudes because of their different cultural backgrounds. The previous studies cannot be regarded as robust and complete as the findings are too general.

However, it is worth noting that Majnun Layla and Liang Shanbo and Zhu Yingtai both come from East culture. Therefore, through comparison, this study intends to explore the underlying reason that causes the differences in defending heroines' love and similarities in attitudes of their parents' arrangements of their marriages from cultural perspective.

In order to enhance a better understanding of the two plays and to deepen readers' aesthetic appreciation of these classic works, this paper intends to explore Layla and Zhu Yingtai's different ways they defended their love and the similar attitudes of their parents' 
arrangements of their marriages from the perspective of cultural difference. Hence, this study seeks to achieve the following objectives:

- to explore the difference between two heroines in defending love;

- to point out the similarities between two heroines in attitudes towards marriage.

According to Boustani (2014), in Arabic literature (and beyond), the legend of Majnun Layla has been rewritten again and again with new interpretations emphasizing different aspects. In many of these versions, both lovers, but particularly the beloved female Layla, become symbolic figures, vehicles for illustrating and debating ideas of the most diverse kind, from mystical through to nationalist approaches, as well as positions critical of culture and society. The common goal of feminism based on the Literary Theory book by Carter is "to raise awareness of women's role in all aspect of literary production (as writers, as characters in literature, as reader, etc.) and to reveal the extent of male dominance in all of these aspects" (2006: 91). The story of Majnun Layla and Liang Shanbo and Zhu Yingtai consists of women characters as the inferior and men character as the superior in all aspects such as family relations, society, and culture. According to the common goal of feminism above, this study also intends to raise the awareness of gender issue and women role in these two plays.

\section{Methodology}

The method used in this research is the textual analysis method. According to Jason (2017), "Textual analysis is a method of study utilized by researcher to examine message as they appear through a variety of mediums. The data generated for textual analysis can come from documents, films, newspapers, paintings, web pages, and so forth. These forms of data serve as the "texts" understudy and are used to assess the meanings, values, and messages being sent through them". That is to say, data is gathered and analyzed to provide a more in-depth understanding of the description and interpretation of the message found in the text.

The legend of Majnun Layla and Liang Shanbo and Zhu Yingtai are two most affecting love stories in Arabic and Chinese culture respectively. Later on, they were recreated by playwrights into tragic plays. They are stand out even more distinctively after they were revised into plays. Out of many versions, the researchers has chosen Ahmad Shawqi's version of Majnun Layla which is written in Arabic, 133 pages long, published by Hindawi company in 2011 and the Xu Jin's version of Liang Shanbo and Zhu Yingtai, written in Chinese, altogether is 96 pages long, published by Shanghai Literature and Art Publishing House in 1979. They both regarded as the most attractive version in their own culture. The data source of this study is taken from these two version of Majnun Layla and Liang Shanbo and Zhu Yingtai based on the sentences and the utterances of female characters that describe their activity and dialogue in these two plays.

\section{Discussion and Results}

Both Majnun Layla and Liang Shanbo and Zhu Yingtai are love tragedies that enjoy high reputations in the Arab world and China. It's well-known that Majnun Layla is a tragedy about young love, hopes and dreams, which Layla's powerful family destroys. Its protagonists are faithful young lovers. The intensity of their love grows stronger as the two get older. Layla is genuinely smitten by love, whereas Qays publicly and unreservedly proclaims his obsessive passion in elegiac lyrics, earning him the moniker Majnun, a mad man, from his tribe and community. Although Layla's father gives her in marriage, against her will, to another man, 
Layla insists on preserving her chastity. Nevertheless, she remains faithful to her true love, Majnun. The story ends with a tragic ending; Layla dies of illness and heartbreak from not seeing her would-be lover, Majnun, who was later found dead in the wilderness.

Similarly, Liang Shanbo and Zhu Yingtai tells a love tragedy about the young lovers separated by the cruel feudal force because of their different social status. The young lover has no choice but to commit suicide to avoid being forced to marry. Both of these tragedies end with the protagonists' tragic deaths. Yet the lovers in Liang Shanbo and Zhu Yingtai are reunited after death as a pair of butterflies.

Majnun Layla and Liang Shanbo and Zhu Yingtai are quite close works to each other in the semantic and humanistic way, and their protagonists are so steady on their love and danger of death cannot awe them. Zhu Yingtai is a picture of Chinese women, and Layla symbolizes Arab women. Despite their lost hope in their lover and cannot do anything to fight for their love, Layla is braver; she expresses her love to Majnun publicly, unlike Zhu Yingtai, burying the love in her heart for more than three years. In the first act, during a conversation with other young men and girls, Layla is suffering because of her love for Majnun, and she says in front of her friends:

"God knows the yearning hidden in my heart for Qays, I am not less than Qays in yearning, and his cup of desire has been my cup. I am betwixt two fires: do not upbraid me, but help me. I am jealous for my honor, and would protect and guard the man I love..." (13-14)

A country's dominating thoughts exert an influence on the formation of the character of its people. The story of Majnun Layla takes place in the Bedouin encampment in the desert. The Bedouin are nomadic Arab tribes who have historically inhabited the desert regions in the Arabian Peninsula. They are traditionally divided into tribes or clans and share a common culture of herding camels and goats. The Bedouin people could be as just as hospitable as they were warring. The national character of Bedouins is unrestrained, outgoing, selfconfident and passionate. In seeking love, Layla's love is demonstrative and passionate and influenced by Bedouin Arabic culture.

On the other side, Zhu Yingtai has affection for Liang Shanbo on her way to Hangzhou, but she does not express her love directly. She buries the love in her heart for more than three years. She says in her soliloquy:

"I often want to give my heart of love to my dear. I feel a sensation burning in my heart, but then it quickly turns in to icy cold. I desire to offer my love, but love I can't." (32)

Compared with Layla, Zhu Yingtai's expressions of love are relatively conservative, deeply influenced by the specific Chinese geographical position. The story of Liang Shanbo and Zhu Yingtai takes place in the East with stable social attitudes. The Chinese culture originated from an agricultural culture. A self-sufficient agricultural economy gradually resulted in a semiclosed social environment, which contributed to forming the Chinese people's restrained and conservative character in ancient times. In most cases, it was disgraceful for a girl to express 
her love for a man in ancient China. Compared to the passionate expressions of Layla, Zhu Yingtai shows her heart implicitly and even secretly turn to her teacher's wife for help when she conveys her sincere love. In the play, Zhu Yingtai finds that Liang Shanbo is a reliable and honest man after three years of staying together, but she is shy to express her admiration for him. Even when they part at the Eighteen-Li Pavilion, Zhu Yingtai conveys her emotions for Liang Shanbo six times indirectly and euphemistically by employing different suggestive images, such as a pair of magpies, and a pair of mandarin ducks, etc. The lack of straightforward expression of love causes Zhu Yingtai to lose the precious opportunity that might have assured their relationship, which indirectly leads to their tragedy.

The heroines in the two plays are madly in love with their beloved, but when their father forces them to marry someone else, they all obey. Set in a Bedouin milieu, it is the tragic story of the love between Majnun and Layla. Early in their youth, Majnun and Layla fall deeply in love with each other, but Majnun's request for Layla's hand is denied because of his social position or the poems he composed praising Layla that defies social norms. Layla's father pushes her to marry another man, she agrees without the slightest hesitation. Layla says in her soliloquy:

\section{"Oh God, what have I said?}

They counselled: would that I had seen more clearly, and ruled my reins! A little hour I yielded

To my temptation, and, in my delirium,

Have slain two hearts. Some devil worked this in me, and let my tongue. I made my little plan,

And fate made his; fate rules the paths of man" (73)

As we can see, Layla's inner feeling reflects her internal contradiction and conflicts and foretell her tragic destiny.

In Liang Shanbo and Zhu Yingtai, Zhu Yingtai also agrees to marry Ma Wencai as her father's wish. When Zhu Yingtai returned home and told her parents her aspiration to marry Liang Shanbo, her father became very annoyed and sneered at her behavior. Then Zhu Yingtai's mother explained hurriedly for her daughter. Her father shouted that:

"We are obedient to her in all things! Can it be rational to agree her marriage with her? I will not allow her to marry Liang Shanbo in any case despite how well she gets on with him or whether they are arranged their marriage without permission or not. Her marriage has been arranged and you don't need to say more" (77).

Zhu Yingtai replied that:

"My father, please don't harm yourself.

I will obey your order and offer myself as an example of filial piety" (78)

From the words of Zhu Yingtai's father, it was apparent that her fate was under the control of her father, and she had no discursive power. Like Layla, they are the picture of Eastern 
women; they obey the social customs and put their family's honour and father's order before their sentiment.

The formation of a person's personality is often determined by his or her social background. Social customs also confine the thoughts and behaviors of people. Layla's father dominates the life of Layla as the leader of the tribe has similar to the definition of patriarchy, where ruler of family, tribe, or church. In contrast, the patriarchy itself is a formal sociological or anthropological category for societies organized into kinship groups and governed or dominated by the elder male (Safrina, \& Kartikasari, 2015). In Bedouin society, women are regarded as beings much inferior to men (Burckhardt, 1831). Bedouin honour codes and hospitality, and courage are some of the Bedouin aspects of ethics. According to Al-Krenawi (2000), Bedouin society is a collective authoritative society in which the family and clan are more important than individuals. The father is the main character in such a patriarchal culture. Therefore, the others accept his authority, who takes his lawful right to rule and make judgments in many parts of their lives. As a result, socialization is authoritative, favoring dependency and conformity over independence and freedom of choice. As a result, the Arab youth's individualization process does not result in self-consolidation or an independent identity.

It is clear that Layla's life is controlled by her father. Here, Layla's response to her father domination shows that she cannot prevent her father decision. Layla should hide her feeling and ascertain if she is happy with her father's decision. As a daughter, Layla believes that she has to respect her father and obey every father's decision. It makes Layla powerless, and she also experiences a culture of silence when she cannot say her voice or opinion to make her own decision.

In ancient China, a marriage should be between families of equal social rank in feudal society. That's why Zhu Yingtai's father does not accept his daughter's idea of marrying Liang Shanbo, a man of poor origin. Although Liang Shanbo and Zhu Yingtai love each other deeply, they dare not revolt against feudal customs. Even when Liang Shanbo visits and talks about marriage, Zhu Yingtai tells him helplessly that she has to obey her parents' orders. Thinking that her parents' orders should not be violated, Zhu Yingtai takes filial ethics into account and agrees to the marriage to comply with ethical standards at the expense of pursuing true love.

Furthermore, the story of Liang Shanbo and Zhu Yingtai take place in the Chinese feudal society when the social position of the female was inferior to that of the male (Zhu, 2014). Zhu Yingtai is one of the representatives of traditional Chinese girls who lived in the shadow of feudalism. In ancient China, obedience is one of the virtues of women in feudal society. Females were required to obey their parents' orders before they got married, especially of their fathers. Under the circumstances, women could not decide on their marriage, and it was natural that parents should decide on marriage.

In feudal society, women's status was worse than men's. They had to defer to men in all things. No matter how competent a woman was, she has to succumb to her husband. The principle of "Obedience to her father before her marriage, her husband after marriage, and her son when her husband is dead" (Li, Guiping, 2010) clearly show the inferior social status of women in the feudal society of China. 
According to Glick and Susan, "the case of women oppression could happen in family and it is called Paternalism that literally means relating to other in the manner of a father dealing with his children" (1996:493). It reveals that women have a huge risk of getting oppression. Moreover, this condition is stimulated by male domination in the environment, and they do not allow women to have more contribution than men in society.

\section{Conclusion}

Majnun Layla and Liang Shanbo and Zhu Yingtai are two classic works enjoying high reputations. In these two plays, two heroines present different ways of defending their love and similar attitudes towards love while influenced by two nations' backgrounds, social backgrounds, and philosophical thoughts. Bedouin nomadism culture caused Bedouins to possess frank and open character and express feelings boldly and straightforwardly, fighting actively for their happiness. However, inland agricultural culture made Chinese people form a more conservative character when faced with love. They did not have enough courage to struggle for their happiness. All these make clear that it is the differences in culture that make the stories and values different.

Nevertheless, there are also some cultural similarities between the Arab world and China. In both societies, the female was inferior to that of the male. Moreover, in both social backgrounds, the father is the dominant figure, whose authority is respected by the children, who also accept his legitimate right to determine and make decisions in many aspects of their life, including marriage. It is clear that in order to understand a literary work better, it is necessary to study the culture behind the literature.

Many studies have compared Romeo and Juliet with Liang Shanbo and Zhu Yingtai and Majnun Layla, respectively. Still, it is hard to find a comparative study between Liang Shanbo and Zhu Yingtai and Majnun Layla, especially from the perspective of a female character. Through the comparison of two famous love tragedies of the Arabic and Chinese literature, the study has drawn out two significant implications. The first implication evolves around Comparative Literature. With the development of Comparative Literature, there is a reason to fill the gap in comparison research between Majnun Layla and Liang Shanbo and Zhu Yingtai to contribute to relevant literature. Secondly, this study has pointed out the similarities and differences between two heroines from the perspective of cultural differences. It contributes to providing a deeper understanding of two different cultures and facilitating the ever-increasing cultural exchange. Cultures are inherently diverse, and their mutual complementarities and mutual developments are possible. Moreover, in modern society, people still confront the problems of women, and the social position between men and women is still not completely equal. This study also gives a better understanding of women position between different cultures and raises awareness of gender issues.

A further study is suggested in the other comparison fields, such as the plot structure, theme, the male characters and plot setting. In addition, other Chinese and Arabic works of literature should be given more opportunities to be studied in the field of comparative literature. 


\section{References}

Al-Krenawi, A. (2000). Ethno-Psychiatry in the Bedouin Arab Society in the Negev. Tel- Aviv: Hakibbutz Hameuhad Publications.

Arberry, A. J. (1993). Ahmad Shawqi, Majnun Layla: A Poetical Drama in Five Acts. Cairo: A. Lencioni Publishers.

Mahmuda, A. (2014). Elements of Comedy in the Verse Dramas of Ahmad Shawqi a Study with Special Reference to Al Sitt Huda and Al Bakhila. Assam University.

Burckhardt, J. L. (1831). Notes on the Bedouins and Wahabys. London: H. Colburn and R. Bentley Publishers.

David, C. (2006). Literary Theory. British: Pocket Essential Publishers.

Cheng, Y. (2002). The Magnificent Sun vs the Graceful Moon - A Proposed Analysis of the Differences Between Romeo and Juliet and The Story of the Butterflies and the Cultural Contributing Factors of These Differences. Journal of Henan Radio \& TV University, 15(1), 33-37.

Ding, S. (2006). A Comparative Study of Arabic, Chinese and English Literature, this study aims to make a comparison between Majnun Layla, Liang Shanbo and Zhu Yingtai and Romeo and Juliet. The Journal of Arabic Language and Literature.

Glick, P., \& Susan, T. F. (1996). The Ambivalent Sexism Inventory: Differentiating Hostile and Benevolent Sexism. Journal of Personality and Social Psychology. Vol.70. No. 3: 491-512.

Matthes, J. (2017). The International Encyclopedia of Communication Research Methods. John Wiley \& Sons Publishers.

Jiao, Y. (2012). A Comparative study on Majnun Layla and Liang Shanbo and Zhu Yingtai. Chinese Journal of Electronic Commerce.

Li, G. (2010). A Comparative Study of Liangzhu and Romeo and Juliet from Cultural Perspective. (Unpublished master dissertation) North University of China.

Avci, N. (2016). Forbidden Love of Shakespeare's Romeo and Juliet and Fuzûlî's Layla and Majnun. International Journal of Literature and Arts, Volume 4, Issue 1-1, January 2016, Pages: 1-4.

Sobhi, B. (2014), Majnūn Laylā in Modern Lebanon: Madness between Lovesickness and Mystical Experience in Hudā Barakāt's Novel Ahl al-hawā. Fabrizio Serra Editore.

Kartikasari, S. D. A. (2015). The Women Struggle of The Story of Layla and Majnun Novel in English Version by DR. Rudolf Gelpke. (Unpublished doctoral dissertation) Indonisia: Yogyakarta: State Islamic University.

Tan, Z. (2007). An analysis on the differences between Romeo and Juliet and Butterfly Lovers. Journal of Wei Fang Educational College, 20(1), 46-47.

$\mathrm{Xu}$, J. (1979). Liang Shanbo and Zhu Yingtai. Shanghai Literature and Art Publishing House.

Zhu, W. (2014). A comparative study of Liang Zhu and Romeo and Juliet from the Perspective. Of Feminism. China: Anhui University. 